\title{
Comments on the Typification of Cheniella glauca (Leguminosae: Cercidoideae)
}

\author{
S. Bandyopadhyay \\ Botanical Survey of India, Central National Herbarium, Howrah 711103, West Bengal, India.
}

*Corresponding Author: Subir Bandyopadhyay, Central National Herbarium, Botanical Survey of India, PO Botanic Garden, Howrah, West Bengal, India.

Abstract: Discussion has been made on the lectotypification of Phanera glauca (三 Cheniella glauca).

Keywords: Phanera glauca, lectotypification, first-step, second-step

\section{INTRODUCTION}

Clark et al. (2017) described a new genus Cheniella R. Clark \& Mackinder and transferred Phanera glauca Wall. ex Benth. under the said genus.

Clark and Mackinder in Clark et al. (2017: 24) designated: Myanmar, Amherst, 1827, Wallich catalogue no. 5785 (K001122119) as the lectotype of Phanera glauca Wall. ex Benth. and cited (K000760783) as the isolectotype. However, it is evident that they overlooked the earlier typification in Larsen and Larsen (1996) where the authors cited "Types: Wallich 5785, Amherst 1827 (K lecto)". Larsen and Larsen (1996) did not use the phrase "designated here" (hic designatus) or an equivalent but as it was prior to 1 January 2001 it has to be considered as an effective lectotypification according to Art. 7.10 of McNeill et al. (2012). There are two specimens at K and one of them (K000760783) has been determined by Supee Larsen as 'Bauhinia glauca (Wall. ex Benth.) Benth. subsp. glauca " in 1973. Still I would like to consider it as lectotype [first-step] because Larsen and Larsen (1996) cited "Types" instead of "Type". Further, though they annotated only one of them, it cannot be evidently proved that they did not examine the other specimens at $\mathrm{K}$. The lectotypification by Clark and Mackinder in Clark et al. (2017) should be considered as correctable to lectotype [second-step] following Art. 9.9. of McNeill et al. (2012).

\section{TYPIFICATION}

Cheniella glauca (Wall. ex Benth.) R. Clark \& Mackinder, Eur. J. Taxon. 360: 24 . 2017.

Phanera glauca Wall. ex Benth. in Miq., Pl. Jungh. 2: 265. 1852.

Lectotype: Myanmar, Amherst, 1827, Wallich catalogue no. 5785 [first-step K001122119 image!, K000760783 image!, designated by Larsen and Larsen (1996)]; [second-step K001122119 image!, designated by Clark and Mackinder (2017)].

\section{ACKNOWLEDGEMENTS}

I thank Dr. Paramjit Singh, Director, Botanical Survey of India, Kolkata and Dr. P.V. Prasanna, Scientist ' $F$ ', Central National Herbarium, Howrah for the facilities.

\section{REFERENCES}

[1] Clark R.P., Mackinder B.A. and Banks H. Cheniella gen. nov. (Leguminosae: Cercidoideae) from southern China, Indochina and Malesia. European Journal of Taxonomy 360, 1-37. 2017.

[2] Larsen K. and Larsen S.S. Bauhinia. In: Kalkman C., Kirkup D. W., Nooteboom H. P., Stevens P. F. and Wilde W.J.J.O. de (Eds.) Flora Malesiana 12(2). Rijksherbarium / Hortus Botanicus, Leiden University, Leiden, pp. 442-535. 1996.

[3] McNeill J., Barrie F.R., Buck W.R., Demoulin V., Greuter W., Hawksworth D.L., Herendeen P.S., Knapp S., Marhold K., Prado J., Prud'homme van Reine W.F., Smith G.F., Wiersema J.H. and Turland N.J. (Eds.) 
International Code of Nomenclature for algae, fungi, and plants (Melbourne Code). Regnum Vegetabile 154. Königstein: Koeltz Scientific Books, 2012.

Citation: S. Bandyopadhyay, "Comments on the Typification of Cheniella glauca (Leguminosae: Cercidoideae) ", International Journal of Advanced Research in Botany, vol. 3, no. 4, p. 40-41, 2017. http://dx.doi.org/10.20431/2455-4316.0304005

Copyright: () 2017 Authors. This is an open-access article distributed under the terms of the Creative Commons Attribution License, which permits unrestricted use, distribution, and reproduction in any medium, provided the original author and source are credited. 